\title{
Modeling Leaf Development of the African Violet (Saintpaulia ionantha Wendl.)
}

\author{
James E. Faust ${ }^{1}$ and Royal D. Heins \\ Department of Horticulture, Michigan State University, East Lansing, MI 48824-1325
}

\begin{abstract}
Additional index words. irradiance, leaf unfolding rate, nonlinear function, temperature
Abstract. Leaf unfolding rate (LUR) was determined for 'Utah' African violet plants grown in growth chambers under 20 combinations of temperature and photosynthetic photon flus (PPF). A nonlinear model was used to predict LUR as a function of shoot temperature and daily integrated PPF. The maximum predicted LUR was 0.27 leaves/day, which occurred at $25 \mathrm{C}$ and a daily integrated $\mathrm{PPF}$ of $10 \mathrm{~mol} / \mathrm{m}^{2}$ per day. The optimum temperature for leaf unfolding decreased to $23 \mathrm{C}$, and the maximum rate decreased to 0.18 leaves/day as the daily integrated PPF decreased from 10 to $1 \mathrm{~mol} / \mathrm{m}^{2} \mathrm{per}$ day. A greenhouse experiment using 12 combinations of air temperature and daily integrated PPF was conducted to validate the LUR model. Plant temperatures used in the model predicted leaf development more accurately than did air temperatures, but using average hourly temperature data was no more accurate than using average daily temperature data.
\end{abstract}

The African violet is an important greenhouse crop in the United States. In 1990, 23 million pots were sold at a wholesale value of \$27.6 million (Agricultural Statistics Board, 1990). Production in the United States peaks at holidays-Valentine's Day is the largest marketing date. Most commercial producers of African violets begin production by purchasing small plants, or "plugs," which usually have 8 to 12 unfolded leaves. The plugs are transplanted into 0.5-liter (lo-cm-diameter) pots, grown, and then sold when the plants have $\approx 20$ to 25 unfolded leaves and five or more open flowers. Production from transplant to anthesis requires 8 to 12 weeks (Fischer, 1991).

Phenology development scales have been used to identify the status of plant development (Hanks and Ritchie, 1991). Vegetative development can be described by leaf number and the rate at which leaves appear, or unfold. Phenological scales are useful to the grower for identifying the current developmental status of a crop and the development required over a future period for a crop to be at the proper stage of development at the market date.

Temperature is the primary variable used in models to predict rates of plant development (Hodges, 1991). Average hourly temperatures (Karlsson et al., 1991), average daily temperatures (Karlsson et al., 1988), and minimum and maximum daily temperature (Hodges and French, 1985) data have been used in plantdevelopment models for different species. Air temperature is most commonly used in leaf-development models.

Photosynthetic photon flux (PPF) is not usually included as a variable in leaf-development models; however, low daily integrated PPF can influence development by limiting the supply of photosynthates. Hanchey (1955) observed that leaf count on African violets increased from 22 to 44 leaves/plant as illuminance increased from 100 to 600 footcandles for $6 \mathrm{~h} /$ day $(0.31$ to $1.9 \mathrm{~mol} /$ $\mathrm{m}^{2}$ per day). Volk and Bugbee (1991) showed a dramatic decrease in leaf emergence rate of wheat as the daily integrated PPF decreased below $10 \mathrm{~mol} / \mathrm{m}^{2}$ per day. The African violet is a shade plant (Johansson, 1978); therefore, commercial producers grow them under shadecloth, which results in maximum integrated PPF of 10 to $15 \mathrm{~mol} / \mathrm{m}^{2}$ per day during the summer months, while the

Received for publication 31 July 1992. Accepted for publication 31 Dec. 1992. We acknowledge the support of the Michigan Agricultural Experiment Station and Express Seed Co., Oberlin, Ohio.The cost of publishing this paper was defrayed in part by the payment of page charges. Under postal regulations, this paper therefore must hereby be marked advertisement solely to indicate this fact.

${ }^{1}$ Graduate Research Assistant.

*Professor of Horticulture. daily integrated PPF delivered to a crop during cloudy, winter conditions can be $<2 \mathrm{~mol} / \mathrm{m}^{2}$ per day. Therefore, the daily integrated PPF delivered to an African violet crop can influence leaf development, so both temperature and PPF need to be considered in the development of a phenology model for African violet.

The objectives of our research were twofold: first, to describe the influence of temperature and PPF on the rate of leaf development of the African violet; and second, to develop a model that would predict leaf development in a greenhouse environment.

\section{Materials and Methods}

Model description. Leaf unfolding rate (LUR), expressed as the number of leaves unfolded per day, describes the rate at which leaves unfold, or appear, at the apical meristem. A leaf was considered unfolded when the leaf blade reached $7 \mathrm{~mm}$ in length. The slope of a linear regression line fit to the number of unfolded leaves as a function of time represented the LUR for a given plant.

The following nonlinear functions (Landsberg, 1977; Reed et al., 1976) were used to describe LUR as a function of both temperature and daily integrated PPF:

$$
\begin{aligned}
& \text { LUR }=A\left(T-T_{\text {Min }}\right)\left(T_{\text {Max }}-T\right)^{B} \\
& A=L_{U R} R_{\text {Max }} /\left(T_{O p t}-T_{\text {Min }}\right)\left(T_{\text {Max }}-T_{O p t}\right)^{B} \\
& B=\left(T_{\text {Max }}-T_{\text {Min }}\right) /\left(T_{O p t}-T_{\text {Min }}\right)
\end{aligned}
$$

where $\mathrm{T}$ is temperature and $\mathrm{T}_{\mathrm{Min}}$ and $\mathrm{T}_{\mathrm{Max}}$ refer to the minimum temperature and the maximum temperature at which LUR is zero. $\mathrm{T}_{\text {Opt }}$ is the temperature at which the maximum LUR occurs for a given daily integrated PPF $\left(\mathrm{PPF}_{\mathrm{DI}}\right)$. $\mathrm{LUR}_{\mathrm{Max}}$ is the value for LUR at $\mathrm{T}_{\mathrm{Opt}}$. The following nonlinear functions were used to describe $\mathrm{T}_{\mathrm{Opt}}$ and $\mathrm{LUR}_{\mathrm{Max}}$ :

$$
\begin{aligned}
& \mathrm{T}_{\mathrm{Opt}}=\mathrm{a}_{0}+\mathrm{a}_{1} \cdot \exp ^{\left(\mathrm{a}_{2} \cdot \mathrm{PPF}_{\mathrm{D}}\right)} \\
& \text { LUR }_{\mathrm{Max}}=\mathrm{b}_{0} \cdot \mathrm{b}_{1} \cdot \exp ^{\left(\mathrm{b}_{2} \cdot \mathrm{PFF}_{\mathrm{D}}\right)}
\end{aligned}
$$

Abbreviations: LUR, leaf unfolding rate; PPF, photosynthetic photon flux. 
where $a_{0}$ and $b_{0}$ indicate the asymptotic values of the functions, and $\mathrm{a}_{1}, \mathrm{a}_{2}, \mathrm{~b}_{1}$, and $\mathrm{b}_{2}$ represent parameter estimates.

Estimating parameters. Parameter estimates and asymptotic 95\% confidence limits for the nonlinear functions used to model leaf development [Eqs. 1-51 were estimated with SAS procedure NLIN (SAS Institute, 1989). In previous experiments, the minimum temperature for leaf growth of the African violet was $\approx 8 \mathrm{C}$ (our unpublished data); therefore, the value of $\mathrm{T}_{\mathrm{MIN}}$, was fixed at $8 \mathrm{C}$.

Design of experiment. 'Utah' African violet plants with 8 to 10 unfolded leaves were transplanted from 3-cm-diameter $\left(22 \mathrm{~cm}^{3}\right)$ cells into 10 -cm-diameter pots $\left(450 \mathrm{~cm}^{3}\right)$ containing a commercial peat-based medium (Baccto Professional Plant Mix, Michigan Peat Co., Houston, Texas). Immediately after transplanting, plants were placed into one of five $\left(15.1-\mathrm{m}^{3}\right)$ walk-in growth chambers (Hotpack, Model UWP 3009-2, Philadelphia). Air temperatures were adjusted to maintain plant temperatures at 14, 18, 22, 26, and $30 \pm 1$. Four PPF treatments were located in each of five temperature treatments. Five plants were grown in each of the 20 temperature/PPF treatments.

Plant temperatures were measured by inserting a hypodermicneedle thermocouple probe (Omega Hyp1-30-1/20-T-G-60-SMP$\mathrm{M})$ into stem, petiole, and leaf tissue. Layers of neutral-density shadecloth were placed above the plants in each growth chamber to create PPF of $23,92,161$, and $230 \mu \mathrm{mol} \cdot \mathrm{m}^{-2} \cdot \mathrm{s}^{-1}$. PPF was supplied $12 \mathrm{~h}$ /day by cool-white fluorescent lamps (Philips VHO F96T12/CW/VHO), which resulted in integrated PPF treatments of $1,4,7$, and $10 \mathrm{~mol} / \mathrm{m}^{2}$ per day. The range of PPF treatments delivered within a chamber resulted in a $\pm 1 \mathrm{C}$ plant-temperature difference between PPF treatments.

Degrees of leaf unfolding were recorded every 2 to 4 days until the first flower had opened on each plant or until day 77 of the experiment. Orthogonal polynomial contrasts were used to determine the trend analyses. SAS procedure GLM (SAS Institute, 1989) was used for analysis of variance.

Validation of the LUR model. Four 10- $\mathrm{m}^{2}$ (floor space) glass houses were set to maintain air temperatures of $15,20,25$, or 30 $\pm 1.5 \mathrm{C}$ from Dec. 1990 to Feb. 1991. Temperatures were controlled by a greenhouse climate-control computer (Priva, Model CD750, De Lier, Holland). Each greenhouse was divided into thirds to provide three PPF treatments. Plants in the low PPF treatment were placed under neutral-density shadecloth to reduce natural PPF by 50\%. Plants in the medium PPF treatment received the natural PPF environment. From 0600 to $1800 \mathrm{HR}$ each day $\left(4.3 \mathrm{~mol} / \mathrm{m}^{2}\right.$ per day), plants in the high PPF treatment received natural PPF plus an additional PPF of $100 \mu \mathrm{mol} \cdot \mathrm{m}^{-2} \cdot \mathrm{s}^{-1}$ supplied by $400-\mathrm{W}$ highpressure sodium lamps (Phillips Electronics Ltd., Model SGH701, Ontario, Canada). Another layer of 50\% PPF-reduction neutraldensity shadecloth was pulled over all PPF treatments when the natural PPF increased above $\approx 300 \mu \mathrm{mol} \cdot \mathrm{m}^{-2} \cdot \mathrm{s}^{-1}$. The average daily integrated PPF was $2.6,4.5$, and $8.8 \mathrm{~mol} / \mathrm{m}^{2}$ per day for each of the three PPF treatments over the course of the experiment.

PPF was monitored at canopy level with LI-COR (LI-190SA, Lincoln, Neb.) quantum sensors. Plant temperature in each treatment was monitored by inserting hypodermic-needle thermocouple probes-into the stem near the apical meristem. Thirtyminute average plant temperatures and PPF measurements were recorded with a datalogger (Easy Logger 800, Omnidata International, Logan, Utah). Air temperature was monitored $30 \mathrm{~cm}$ above the canopy with a shaded and aspirated thermocouple. Two-hour average air temperatures also were recorded with a datalogger (Digistrip III, Kaye Instruments Co., New Bedford, Conn.).

All plants were subirrigated with a nutrient solution consisting of $3.6 \mathrm{mmol} \mathrm{N}$ and $1.3 \mathrm{mmol} \mathrm{K}$ from calcium and potassium nitrate or were watered based on the electrical conductivity of the medium. Electrical conductivity of the medium in the root zone was maintained between 0.5 and $1.0 \mathrm{mS} \cdot \mathrm{cm}^{-1}$ throughout the experiment using the 2 water : 1 soil (v/v) method (Warncke and Krauskopf, 1983). The electrical conductivity of the irrigation water was $0.65 \mathrm{mS} \cdot \mathrm{cm}^{-1}$ and the bicarbonate alkalinity was 310 $\mathrm{mg} \cdot$ liter $^{-1}$. Phosphoric acid $(85 \%)$ at 0.25 to $0.5 \mathrm{ml}$ per liter of irrigation water was applied to the medium as needed to maintain media $\mathrm{pH}$ between 5.5 and 6.5 .

Tests of model prediction. Four methods of averaging actual temperature data were compared when the LUR model was validated. The methods were based on: 1) average hourly plant temperature; 2) average hourly air temperature; 3) average daily plant temperature; and 4) average daily air temperature. The calculated average temperatures were used along with the daily integrated PPF to predict LUR on either an hourly or daily basis.

Two techniques were used to compare the predictive usefulness of the four methods of using temperature data in the LUR model. First, the absolute deviation between actual and predicted leaf count was calculated for each recorded leaf count. Second, the slope of the observed leaf count plotted against the predicted leaf count was calculated by linear regression. Accurate prediction of LUR would result in a slope equal to one; therefore, the absolute deviation between the slope of the predicted leaf count and the slope of the observed leaf count provided another comparison of the methods for entering temperature data into the LUR model.

\section{Results}

The leaves of each plant unfolded as a linear function of time for the $22 \mathrm{C} / 7-\mathrm{mol} / \mathrm{m}^{2}$ per day treatment (Fig. 1); all other treatments produced similar results. Temperature, daily integrated PPF, and the interaction between temperature and daily integrated PPF influenced LUR significantly. LUR increased as temperature increased from $14 \mathrm{C}$ to an optimum temperature, and then decreased sharply as temperature increased above the optimum temperature. LUR also increased at all temperatures as daily integrated PPF increased from 1 to $7 \mathrm{~mol} / \mathrm{m}^{2}$ per day, but did not increase further at $10 \mathrm{~mol} / \mathrm{m}^{2}$ per day (Fig. 2).

The model [Eqs. 1-51 predicted LUR based on temperature and daily integrated PPF data (Fig. 2). The interaction between tem-

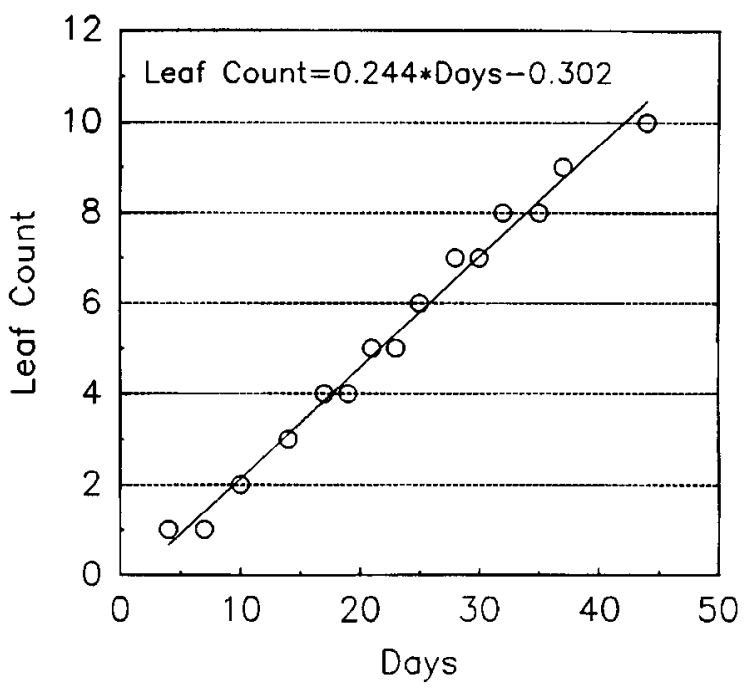

Fig. 1. The rate of leaf unfolding for an African violet grown at $22 \mathrm{C}$ and a daily integrated PPF of $7 \mathrm{~mol} / \mathrm{m}^{2}$ per day was 0.244 leaves/day, as determined by the slope of the regression line $\left(R^{2}=0.99\right)$. 


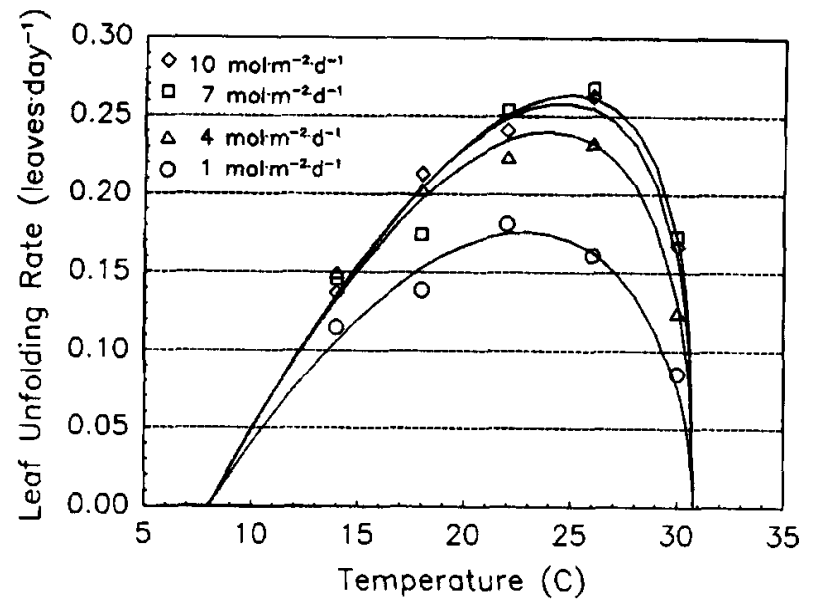

Fig. 2. Nonlinear model [Eqs. 1-5] describing LUR as a function of temperature and daily integrated PPF $\left(R^{2}=0.99\right)$. Symbols represent treatment means.

Table 1. Parameter estimates and $95 \%$ confidence intervals calculated for use in the LUR model for African violets [Eq. 1-5].

\begin{tabular}{|c|c|c|c|c|}
\hline \multicolumn{2}{|c|}{ Parameter } & \multirow[b]{2}{*}{ Estimate } & \multicolumn{2}{|c|}{$\begin{array}{l}\text { Asymptotic } 95 \% \\
\text { confidence interval }\end{array}$} \\
\hline Eqs. 1-3 & Eqs. 4 and 5 & & Lower & Upper \\
\hline $\mathrm{T}_{\mathrm{Max}}$ & & 30.83 & 30.36 & 31.31 \\
\hline \multirow[t]{3}{*}{$\mathrm{T}_{\mathrm{Opt}}^{\mathrm{Max}}$} & $\mathrm{a}_{0}$ & 25.44 & 23.22 & 27.66 \\
\hline & $a_{1}$ & -3.127 & -4.861 & -1.392 \\
\hline & $a_{2}$ & -0.193 & -0.559 & 0.173 \\
\hline \multirow[t]{3}{*}{ LUR $_{\text {Max }}$} & $\mathrm{b}_{0}$ & 0.266 & 0.252 & 0.280 \\
\hline & $b_{1}$ & -0.137 & -0.162 & -0.112 \\
\hline & $b_{2}$ & -0.418 & -0.621 & -0.215 \\
\hline
\end{tabular}
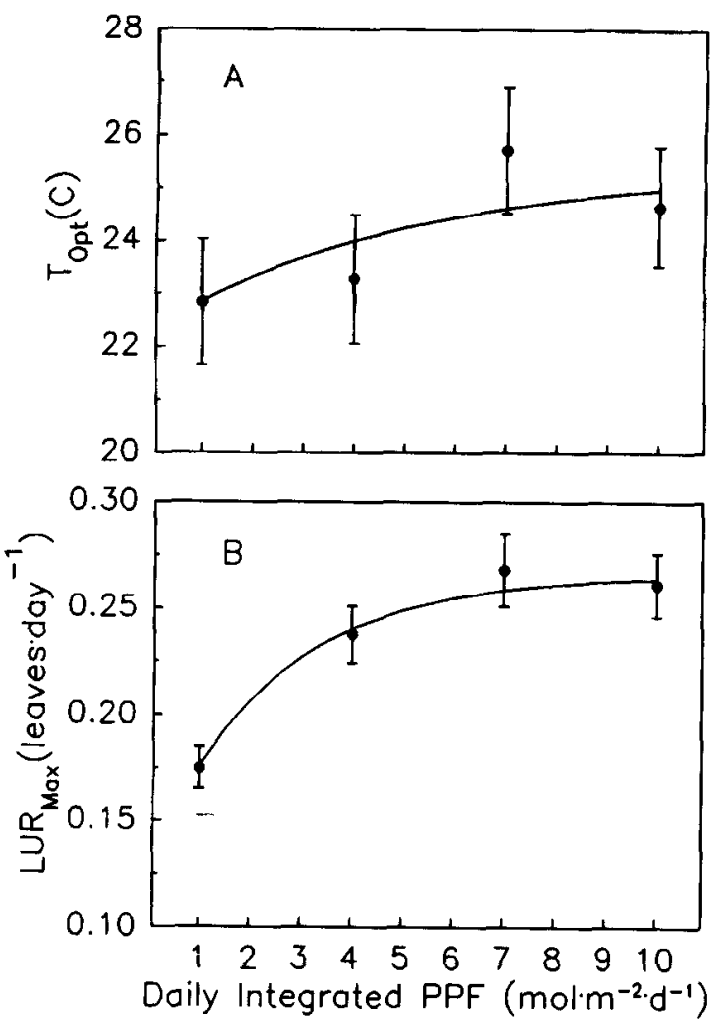

Fig. 3. The influence of daily integrated PPF on (A) $\mathrm{T}_{\mathrm{Op}}[\mathrm{Eq} .4]$ and (B) LUR $\mathrm{Lax}_{\mathrm{Max}}[\mathrm{Eq}$ 5]. Vertical bars indicate asymptotic $95 \%$ confidence intervals for $\mathrm{T}_{\mathrm{Opt}}$ and
LUR $_{\text {Max }}$ values estimated at each daily integrated PPF treatment. perature and daily integrated PPF for the parameters estimates was represented by the increase in $\mathrm{T}_{\mathrm{Opt}}$ and $\mathrm{LUR}_{\mathrm{Max}}$ with daily integrated PPF (Table 1). $\mathrm{T}_{\text {Opt }}$ increased from 22.6 to 25.5C (Fig. 3A), and $\mathrm{LUR}_{\mathrm{Max}}$ increased from 0.18 to 0.27 leaves/day (Fig. 3B) as the daily integrated PPF increased from 1 to $10 \mathrm{~mol} / \mathrm{m}^{2}$ per day.

In the model-validation experiment, average hourly air temperatures were usually maintained within $\pm 1.5 \mathrm{C}$ of the setpoint temperature, while plant temperature frequently differed from air temperature. Plant temperature during the photoperiod was closely related to the instantaneous solar radiation. Plant temperature during the daylight hours on cloudy days was often 1 to $3 \mathrm{C}$ below air temperatures (Fig. 4A), while plant temperature during the daylight hours on sunny days was up to $4 \mathrm{C}$ higher than air temperature (Fig. 4B). Plant temperature during the night was typically 2 to $5 \mathrm{C}$ lower than air temperature (Fig. 4A-C). Plant temperature increased 3 to $4 \mathrm{C}$ when the high-pressure sodium lamps were used (Fig. 4C).

Plant temperatures predicted leaf count more accurately than did air temperatures, based on a comparison between actual and predicted leaf counts. The mean deviation between the predicted and observed leaf counts was $63 \%$ larger for data based on air temperature than on plant temperature. The deviation between the slopes of the predicted and actual leaf counts increased $58 \%$ when air temperatures were used instead of plant temperatures. The precision of the model was not improved by using average hourly rather than average daily temperatures (Table 2).

The LUR model [Eqs. 1-5] accurately predicted leaf unfolding

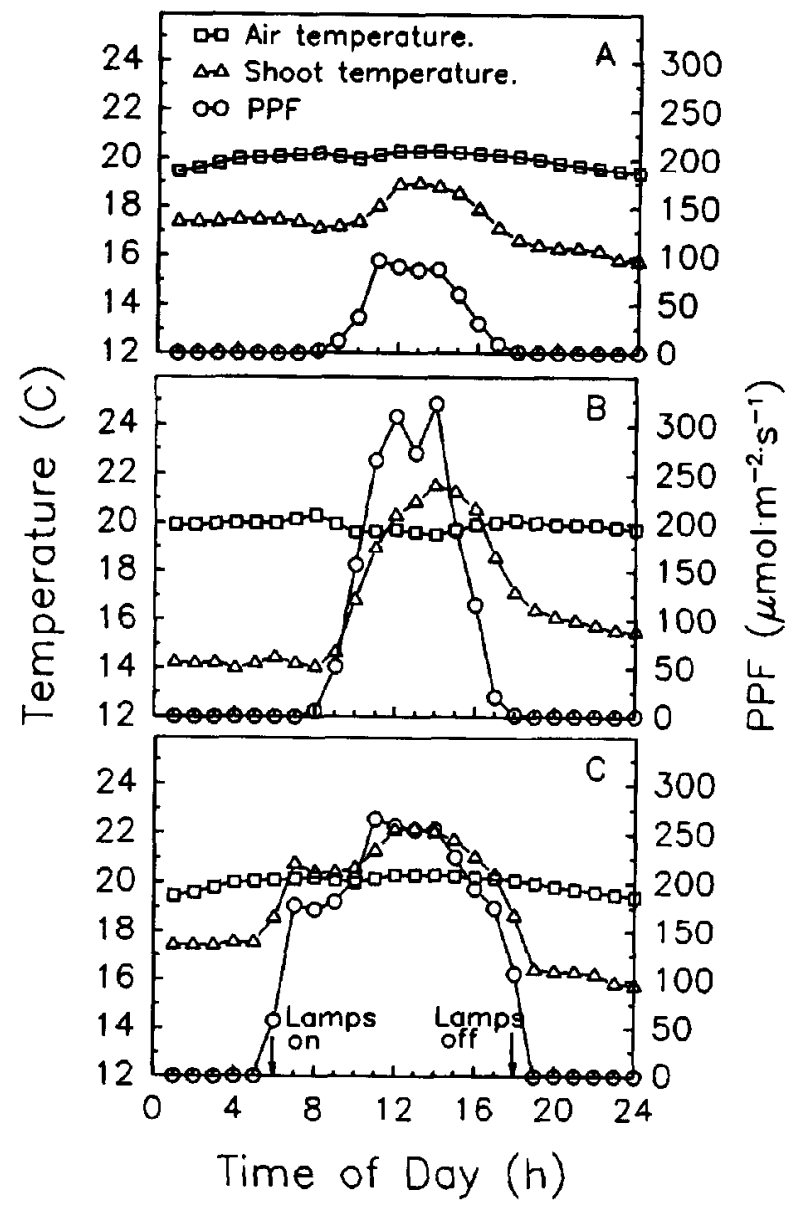

Fig. 4. A comparison between air and plant temperature (A) over the course of a cloudy day (30 Dec. 1990), (B) a sunny day (3 Jan. 1991), and (C) a cloudy day in which the plants were growing under high-pressure sodium lamps from 0600 to 1800 HR (30 Dec. 1990). 
Table 2. Comparison of four methods of using temperature data to predict leaf count in African violets.

\begin{tabular}{|c|c|c|c|c|c|c|c|c|c|}
\hline \multirow[b]{4}{*}{$\begin{array}{l}\text { Air } \\
\text { temp }\left({ }^{\circ} \mathrm{C}\right)\end{array}$} & \multirow[b]{4}{*}{$\begin{array}{c}\text { Daily integrated } \\
\mathrm{PPF}\left(\mathrm{mol} / \mathrm{m}^{2} \text { per day }\right)\end{array}$} & \multicolumn{4}{|c|}{ Avg. temp } & \multicolumn{4}{|c|}{ Avg. temp } \\
\hline & & \multicolumn{2}{|c|}{ Hourly } & \multicolumn{2}{|c|}{ Daily } & \multicolumn{2}{|c|}{ Hourly } & \multicolumn{2}{|c|}{ Daily } \\
\hline & & Plant & Air & Plant & Air & Plant & Air & Plant & Air \\
\hline & & \multicolumn{4}{|c|}{$\begin{array}{l}\text { Deviation between predicted and } \\
\text { observed leaf counts (no. leaves) }\end{array}$} & \multicolumn{4}{|c|}{$\begin{array}{l}\text { Deviation between slopes of the predicted } \\
\text { and actual leaf counts (no. leaves) }\end{array}$} \\
\hline \multirow[t]{3}{*}{$\overline{15}$} & 2.6 & 0.53 & 1.47 & 0.49 & 1.38 & 0.07 & 0.22 & 0.07 & 0.24 \\
\hline & 4.5 & 0.94 & 2.22 & 1.07 & 2.13 & 0.16 & 0.35 & 0.21 & 0.36 \\
\hline & 8.8 & 1.57 & 0.76 & 1.23 & 1.38 & 0.26 & 0.12 & 0.14 & 0.11 \\
\hline \multirow[t]{3}{*}{20} & 2.6 & 0.70 & 0.89 & 0.72 & 0.78 & 0.16 & 0.07 & 0.11 & 0.06 \\
\hline & 4.5 & 0.92 & 1.40 & 0.95 & 1.32 & 0.07 & 0.18 & 0.11 & 0.20 \\
\hline & 8.8 & 0.73 & 0.86 & 0.72 & 0.76 & 0.08 & 0.05 & 0.05 & 0.05 \\
\hline \multirow[t]{3}{*}{25} & 2.6 & 0.87 & 0.69 & 0.69 & 0.62 & 0.22 & 0.15 & 0.15 & 0.13 \\
\hline & 4.5 & 0.93 & 1.06 & 0.84 & 0.90 & 0.15 & 0.08 & 0.10 & 0.08 \\
\hline & 8.8 & 1.02 & 0.60 & 0.79 & 0.70 & 0.15 & 0.10 & 0.11 & 0.10 \\
\hline \multirow[t]{3}{*}{30} & 2.6 & 0.73 & 2.90 & 0.50 & 2.82 & 0.07 & 0.61 & 0.05 & 0.50 \\
\hline & 4.5 & 0.67 & 2.09 & 0.85 & 1.81 & 0.05 & 0.37 & 0.07 & 0.28 \\
\hline & 8.8 & 0.99 & 1.52 & 0.71 & 1.41 & 0.13 & 0.29 & 0.06 & 0.21 \\
\hline $\operatorname{Mean}^{\mathrm{z}}$ & & $0.88 \mathrm{a}$ & $1.37 \mathrm{~b}$ & $0.79 \mathrm{a}$ & $1.29 \mathrm{~b}$ & $0.13 \mathrm{a}$ & $0.21 \mathrm{~b}$ & $0.10 \mathrm{a}$ & $0.19 \mathrm{~b}$ \\
\hline
\end{tabular}

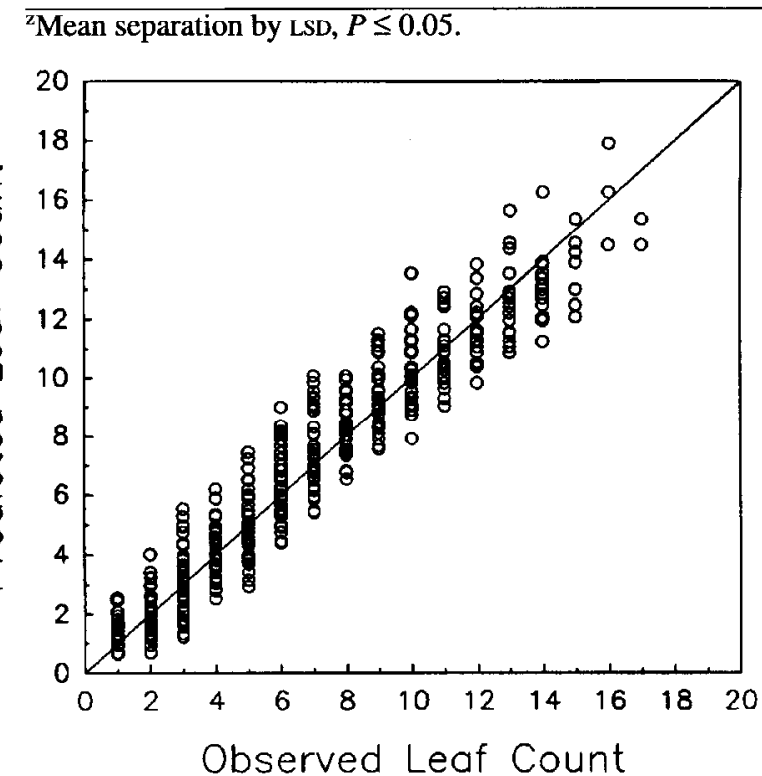

Fig. 5. Comparison between the predicted (solid line) and observed (circles) leaf count of plants grown in a greenhouse under 12 temperature/PPF treatments.

over 77 days of the validation experiment (Fig. 5). Predicted leaf count was within one leaf of the observed leaf count $84 \%$ of the time (more than 300 measurements on 48 plants) when average daily plant temperatures were used in the model (Fig. 6).

\section{Discussion}

The influence of temperature on leaf development of African violets was similar to that on other plant species. In African violets, we estimated $\mathrm{T}_{\text {MIN }}$ to be $8 \mathrm{C}, \mathrm{T}_{\text {Opt }}$ to be between 23 and $25.5 \mathrm{C}$, and $\mathrm{T}_{\text {Max }}$ to be $30.8 \mathrm{C}$-temperatures similar to those determined for other tropical species (Kiniry et al., 1991). LUR Max $_{\text {varies consid- }}$ erably from 0.10 leaves/day for banana (Musa paradisiaca L.) (Allen et al., 1988) to 2.5 leaves/day for the Easter lily (Lilium longiflorum Thunb.) (Karlsson et al., 1988). $\mathrm{LUR}_{\mathrm{Max}}$ for African violets was 0.27 leaves/day, which occurred on plants grown at $26 \mathrm{C}$ and $10 \mathrm{~mol} / \mathrm{m}^{2}$ per day.

Leaf development was influenced by daily integrated PPF. PPF is not typically used in plant development models because the daily integrated PPF at which most crops are produced is sufficiently high to saturate the photosynthetic apparatus. However, African violets are susceptible to physiological damage at high PPF, so growers often produce African violets at PPF that limit photosynthesis and leaf development. Therefore, daily integrated PPF was included as a variable in the LUR model.

No significant differences resulted from using average hourly temperatures in the model as compared to average daily temperatures. Similar results have been observed by researchers using degree-day models (Cross and Zuber, 1972; Gilmore and Rogers, 1958). The temperature-response curves used in the LUR model were developed from data collected on plants grown at constant temperatures, but these response curves may not reflect the developmental responses that occur during brief exposures to temperatures outside the linear-response range. Therefore, the model reflects development rates that occur over broader time intervals; thus, average daily temperatures were the most accurate for predicting leaf development.

Plant temperatures gave a more accurate prediction of leaf count with the LUR model than did air temperatures. The actual tissue temperature of the developing plant must be determined to predict specific organ or tissue development accurately. Harris and Scott (1969) independently fluctuated the temperature of carnation (Dianthus caryophyllus L.) flower buds and leaves and observed that the temperature of an organ determined the development rate for that organ.

Plant temperature depends on the energy exchange between the plant and its environment. During the night period of the greenhouse experiment, plant temperatures were frequently 2 to $5 \mathrm{C}$ below air temperature. Part of this temperature difference can be attributed to net energy loss to the greenhouse glass via longwave radiation (Hanan et al., 1978). However, we also have observed a 1 to $3 \mathrm{C}$ drop in temperature of African violets during dark periods in growth chambers. Vogelezang (1988) observed that meristem temperature of African violets is correlated more closely with soil temperature than air temperature. African violet has a rosette growth habit, and the meristem is typically $<3 \mathrm{~cm}$ above the soil surface. Therefore, we hypothesize that the observed difference between air and plant temperature is due in part to evaporative cooling occurring from the wet soil surface. 


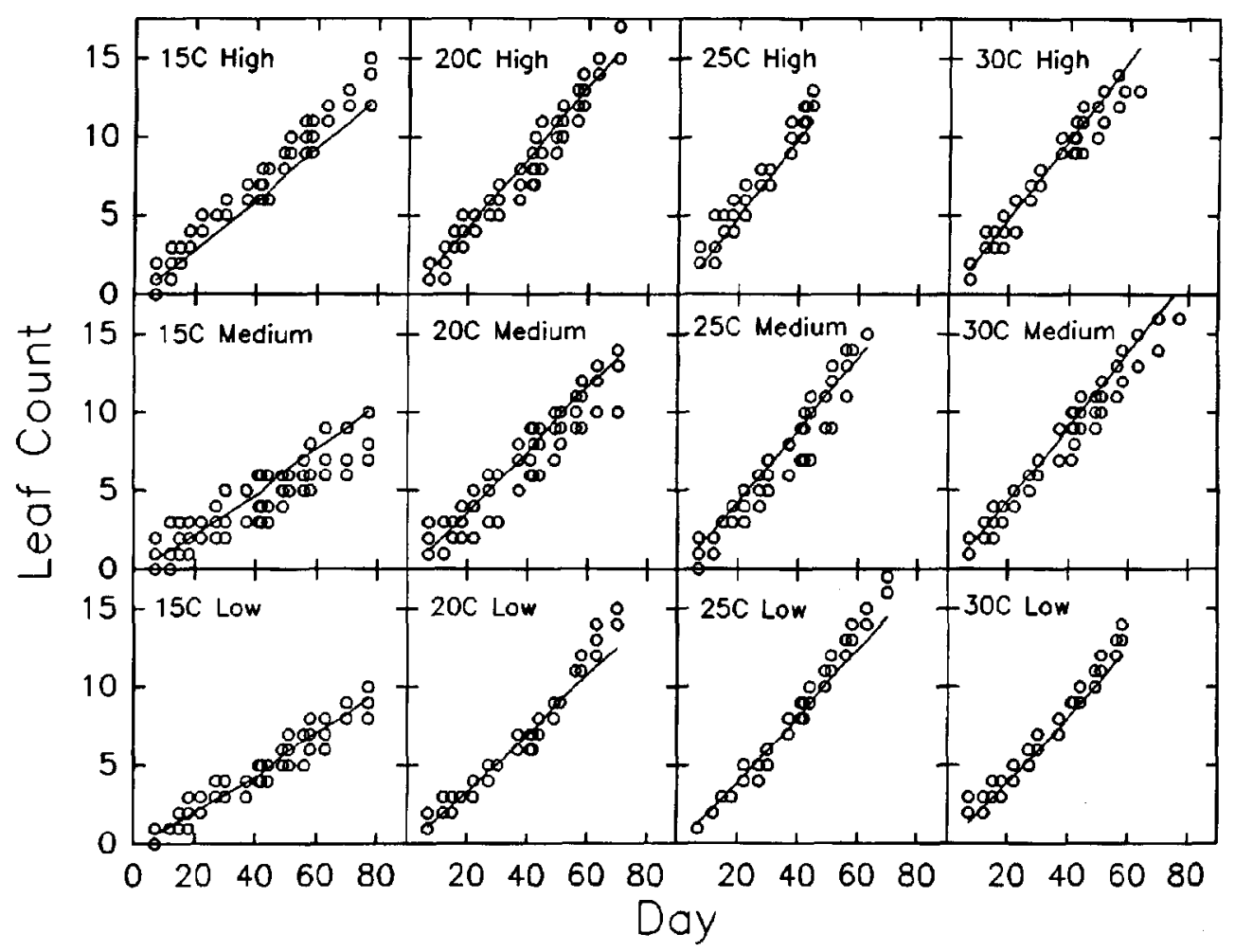

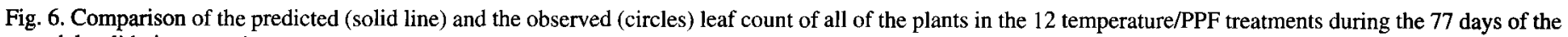
model-validation experiment.

In summary, a LUR model based on average daily plant temperatures and daily integrated PPF accurately predicted leaf development of African violets grown for 77 days in a greenhouse under a range of air temperatures from 15 to $30 \mathrm{C}$ and PPF from 2.6 to $8.8 \mathrm{~mol} / \mathrm{m}^{2}$ per day. Plant temperature predicted leaf development more accurately than did air temperature. No benefit was obtained by using average hourly temperatures rather than average daily temperatures.

\section{Literature Cited}

Agricultural Statistics Board. 1990. Floriculture crops: 1990 Summary. USDA, Natl. Agr. Stat. Serv., Agr. Stat. Board, Washington, D.C.

Allen, R.N., E.B. Dettmann, G.G. Johns, and D.W. Turner. 1988. Estimation of leaf emergence rates of bananas. Austral. J. Agr. Res. 39:53-62. Cross, H.Z. and M.S. Zuber. 1972. Prediction of flowering dates in maize based on different methods of estimating thermal units. Agron. J. 64:351-355.

Fischer, A.W. 1991. Saintpaulia ionantha, p. 759-62. In: V. Ball (ed.). Ball red book. 15th ed. Geo. J. Ball Publishing, West Chicago, Ill.

Gilmore, E.C. and J.S. Rogers. 1958. Heat units as a method of measuring maturity in corn. Agron. J. 50:611-615.

Hanan, J.J., W.D. Holley, and K.L. Goldsberry. 1978. Greenhouse management. Springer-Verlag Berlin. p. 130-151.

Hanchey, R.H. 1955. Effects of fluorescent and natural light on vegetative and reproductive growth in Saintpaulia. Proc. Amer. Soc. Hort. Sci. 66:379-382.

Hanks, J. and J.T. Ritchie. 1991. Modeling plant and soil systems. Agron. Monogr. 31.

Harris, G.P. and M.A. Scott. 1969. Studies on the glasshouse carnation: Effects of light and temperature on the growth and development of the flower. Ann. Bot. 33:143-152.

Hodges, T. 1991. Temperature and water stress effects on phenology, p. 7-13. In T. Hodges (ed.). Predicting crop phenology. CRC Press, Boca Raton, Fla.

Hodges, T. and V. French. 1985. Soyphen: Soybean growth stages modeled from temperature, daylength, and water availability. Agron J. 77:500-505.

Johansson, D.R. 1978. Saintpaulias in their natural environment with notes on their present status in Tanzania and Kenya. Biol. Conserv. 14:45-62.

Karlsson, M.G., R.D. Heins, and J.E. Erwin. 1988. Quantifying temperature-controlled leaf unfolding rates in 'Nellie White' Easter lily. J. Amer. Soc. Hort. Sci. 113(1):70-74.

Karlsson, M.G., R.D. Heins, J.O. Gerberick, and M.E. Hackmann. 1991. Temperature-driven leaf unfolding rate in Hibiscus rosa-sinensis. Scientia Hort. 45:323-331.

Kiniry, J.R., W.D. Rosanthal, B.S. Jackson, and G. Hoogenboom. 1991. Predicting crop phenology. CRC Press, Boca Raton, Fla.

Landsberg, J.J. 1977. Some useful equations for biological studies. Expl. Agr. 13:273-286.

Reed, K.L., E.R. Hamerly, R.F. Dinger, and P.G. Jarvis. 1976. An analytical model for field measurement of photosynthesis. J. Applied Ecol. 13:925-942.

SAS Institute. 1989. SAS/STAT user's guide, vers. 6, 4th ed. vol. 2, SAS Institute, Inc., Cary, NC.

Vogelezang, J.V.M. 1988. Effect of root-zone heating on potplants. Acta Hort. 229:421-427.

Volk, T. and B. Bugbee. 1991. Modeling light and temperature effects on leaf emergence in wheat and barley. Crop Sci. 31: 1218-1224.

Warncke, D. and D. Krauskopf. 1983. Greenhouse growth media: testing and nutrition guidelines. Mich. State Univ. Ext. Bul. E-1736. 